\section{Effects of Seed Treatments and Planting Depth on Emergence of Sea Buckthorn Species}

\author{
Thomas S.C. Li and \\ D ouglas A. Wardle
}

\begin{abstract}
AdDitional INDEX words. H ippophae rhamnoi des, $\mathrm{H}$ i ppophae ti betana, H i ppophae neurocarpa, $\mathrm{H}$ i ppophae sali difolia, H i ppophae rhamnoi des subsp. rhamnoi des, sinensis, turkestanica, mongolica
\end{abstract}

\begin{abstract}
Summary. The influence of seed treatments and planting depth on the percentage of seed emergence of H i ppophae rhamnoi des L. 'I ndianSummer', H . ti betana Schlecht., H . neurocarpa Liu \& H e, H . salicifolia D Don, and $H$, rhamnoidessubsp. rhamnoides sinensis, turkestanica, and mongolica were studied. Surface seeding had higher percentages of seed emergence and more rapid completion of emergence compared to a 1- or 2-cm (0.4- or 0.8-inch) seeding depth. Seeds soaked in water or potassium nitrate solution at room temperature emerged in higher percentages. Average plant height of the eight species and subspecies varied significantly at the end of first growing season.
\end{abstract}

S ea buckthorn (H ippophae rhamnoides) is a new crop that has great economic potential in North America. It is a hardy, deciduous shrub, ideal for soil erosion control, land reclamation, wild lifehabitat enhancement, and farmstead protection ( $\mathrm{L}$ and Schroeder, 1996). Recently, sea buckthorn has attracted considerable attention from researchers around the world for itsnutritional

$\overline{\text { Agriculture and Agri-Food C anada, Pacific Agri-Food }}$ Research Centre, Summerland, B.C., C anada.

Contribution 1062. The cost of publishing this paper was defrayed in part by the payment of page charges. U nder postal regulations, this paper therefore must be hereby marked advertisement solely to indicate this fact. and medicinal values ( $\mathrm{Li}$ and Wang, 1998). Plantations in Canada are mainly found in shelterbelts on the prairies. In the last few years, acreage in orchard-type cultivation of $\mathrm{H}$. rhamnoides 'I ndian-Summer' has increased rapidly in both B ritish C olumbia and Saskatchewan, and seeds or seedlings are in great demand.

The simplest method for propagating sea buckthorn is by seed. Sea buckthorn seedsrequire no special seed bed preparation, and a large number of seedlingscan be produced in a short period of time. $M$ any factors affect seed germination: seed source (F efelov and Eliseev, 1986), maturity (Eliseev and Mishulina, 1972a; Vernik and Zhapakova, 1986), dormancy (Siabaugh, 1974), preseeding treatments ( $\mathrm{L} i$ and Schroeder, 1996; Lu, 1992), planting media (Salo, 1991), seeding depth ( $\mathrm{Li}$ and Schroeder, 1996), and soil and environmental conditions (Vernik and Zhapakova, 1986). Limited information is available regarding seed treatments and germination of $\mathrm{H}$ ippophaespecies. The objectives of this study were to investigate the effects of seed treatments [ soaking in water at room temperature $20^{\circ} \mathrm{C}\left(68^{\circ} \mathrm{F}\right)$, in water initially at $70^{\circ} \mathrm{C}$ $\left(158{ }^{\circ} \mathrm{F}\right)$, in $500 \mathrm{mg} \cdot \mathrm{L}^{-1} \mathrm{GA}_{3}$ or in $0.01 \mathrm{~m}$ potassium nitrate solution for $48 \mathrm{~h}$ ] and seeding depth on the percentage of seed emergence and number of days required to start and complete emergence. Plant height of different sea buckthorn species was al so evaluated at the end of the first growing season.

\section{Materials and methods}

Seeds of $\mathrm{H}$. rhamnoides 'I ndianSummer', $H$. tibetana, $H$. neurocarpa, $H$. sali cifolia, and $H$. rhamnoi dessubsp. rhamnoides, sinensis, turkestanica, and mongolica were collected in 0 ctober 1996, 1 year before the experiment. Seeds were removed from berries, washed with water, air dried and stored in cool [ 1 to $2^{\circ} \mathrm{C}$ (34 to $\left.36^{\circ} \mathrm{F}\right)$ ] storage. Five preseeding seed treatments were 1) control (nontreated), 2) soaked in water at room temperature $\left.\left[20^{\circ} \mathrm{C}\left(68{ }^{\circ} \mathrm{F}\right)\right], 3\right)$ soaked in water initially at $70{ }^{\circ} \mathrm{C}\left(158{ }^{\circ} \mathrm{F}\right)$ and allowed to cool to room temperature, 4) soaked in $\mathrm{GA}_{3}\left(500 \mathrm{mg} \cdot \mathrm{L}^{-1}\right)$ solution, and 5) soaked in $0.01 \mathrm{~m}$ potassium nitrate $\left(\mathrm{KN} \mathrm{O}_{3}\right)$. All seed soaking treatments were for $48 \mathrm{~h}$.

Seeds were planted immediately 
T able 1. E ffects of seeding depths and seed treatments on the percentage of seed emergence in sea buckthorn.

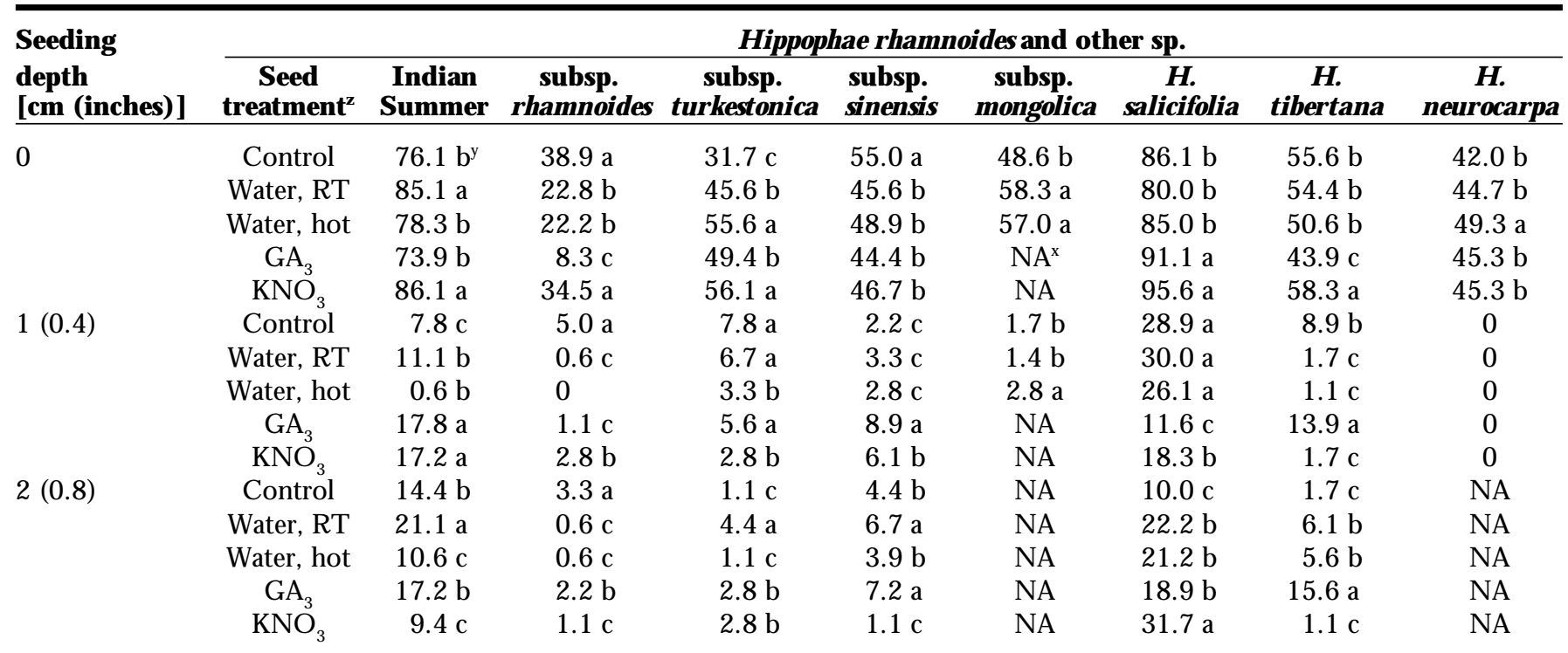

zSeed treatment: water, RT (room temperature) = soaked in water under room temperature $\left[20^{\circ} \mathrm{C}\left(68^{\circ} \mathrm{F}\right)\right]$; water, hot $=$ soaked in preheated $\left[70{ }^{\circ} \mathrm{C}\left(158^{\circ} \mathrm{F}\right)\right.$ water and allowed to cool to room temperature; $\mathrm{GA}_{3} 500 \mathrm{mg} \cdot \mathrm{L}^{-1}$ solution; $\mathrm{KNO}_{3}=$ soaked in potassium nitrate at $0.01 \mathrm{M}$.

'Values within each column and within a seeding depth with a common letter are not significantly different $(p=0.05)$ according to $D$ uncan's new multiple range test. ×N A = not applied.

after treatments at three depths: 1) on the surface, 2) $1 \mathrm{~cm}(0.4$ inch), or 3$)$ $2 \mathrm{~cm}$ (0.8 inch). There were eight replications (pot) per combination of five preseeding treatments and three seeding depths [total of 120 pots/ species, 30 seeds/ pot, $12 \mathrm{~cm}^{2}$ (4.7 inches $\left.{ }^{2}\right)$ ]. D ue to the limited number of seeds available for $\mathrm{H}$. rhamnoides subsp. mongolica and $\mathrm{H}$. neurocarpa, only two seeding depths-surface and $1 \mathrm{~cm}$-were tested. Pots were filled with Sunshine M ix \#2 (peatmoss and perlite mixture, Growers Supply Co., Kelowna, B.C.) and arranged separately by species in a completely random design in growth chamber [25/ $20^{\circ} \mathrm{C}\left(77 / 68^{\circ} \mathrm{F}\right.$, day/ night), with a 16-h photoperiod and a light intensity of $150 \mu \mathrm{mol} \cdot \mathrm{m}^{-2} \mathrm{~s}^{-1}$ ], $1 \mathrm{~m}(3.3 \mathrm{ft})$ above the pot].

E merged seedlings were counted every $2 \mathrm{~d}$. Percentage of seed emergence and number of days to start and to complete emergence (the first day of achieving the highest number of seedlings emerged) were recorded. In total, 40 seedlings per species were transplanted individually into pots [ 12 $\mathrm{cm}^{2}\left(4.7\right.$ inch $\left.^{2}\right)$ ] filled with Sunshine $\mathrm{M}$ ix \#2 after emergence was complete. Potswerefertigated once every 2 weeks with $250 \mathrm{~mL}$ ( $8.45 \mathrm{fl} \mathrm{oz}$ )/ pot of $20 \mathrm{~N}$ 8.7P-16.6K [0.5 g. $\mathrm{L}^{-1}$ (500 ppm)] (Plant ProductsC o., Brampton, O nt.). After 6 weeks in the growth chamber, seedlings of all eight species or subspecieswere transplanted to the field with sandy loam soil- $70 \%$ sand, $16 \%$ clay, $14 \%$ silt-based on Canadian System of Soil Classification [M cKeague, 1978; pH 6.9, organic matter 4.3\%, salts $0.40 \mathrm{dS} \cdot \mathrm{m}^{-1}$, and (in $\mathrm{mg} \cdot \mathrm{L}^{-1}$ ) $8 \mathrm{~N}-$ $23 \mathrm{P}-133 \mathrm{~K}-228 \mathrm{M} \mathrm{g}-1182 \mathrm{Ca}-22 \mathrm{~N} \mathrm{a}$ 23S-3.06B-0.7Cu-20.8Fe-6.6M n$32.8 \mathrm{Zn}$. Spacing was $1 \mathrm{~m}$ between rowsand $0.5 \mathrm{~m}$ (1.6ft) within the row. E ight plants per block per species and four blocks were laid out in a randomized complete-block design. Plant height was measured immediately after transplanting and at the end of the growing season. Analyses of variance by the general linear models (GLM) procedure, and mean comparisons by D uncan'snew multiple rangetest were performed according to SAS methods (SAS I nstitute Inc., 1990).

\section{Results and discussion}

Surface planting significantly improved seed emergence percentage compared to seeding depths of 1 or 2 $\mathrm{cm}$, suggesting that sea buckthorn seedsarelight sensitive (T able 1). G ood emergence percentage from surface seeding was an important factor in the success of aerial sowing of sea buckthorn in the L oessPlateau of $C$ hina $(\mathrm{Li}$ et al., 1995). Seed emergence varied from $31.7 \%$ for $\mathrm{H}$. rhamnoi des subsp. turkestanica to $86.1 \%$ for H . salicifolia in nontreated controls (Table 1). $\mathrm{H}$ igher emergence percentage with similar variation among species were reported by Zu et al. (1993). Percent- age of seed emergence was poor at a 1or 2-cm planting depth for all species, and burying the seed prevented emergence completely for $\mathrm{H}$. neurocarpa.

When the seeds were planted at the soil surface, preseeding treatments improved seed emergence in all the species tested except $\mathrm{H}$. rhamnoides subsp. rhamnoides and sinensis (Table 1). Generally, soaking seeds either in water or potassium nitrate solution at room temperature for $48 \mathrm{~h}$ improved seed emergence compared with the nontreated control. Eliseev and M ishulina (1972b) obtained similar results, as they found that steeping $\mathrm{H}$. rhamnoi desseedsin $0.02 \% \mathrm{KI}$ or $0.05 \%$ $\mathrm{ZnSO}$ solutionsincreased emergence by $12 \%$ and $9.1 \%$ respectively.

Lu (1992) reported, without giving any numbers, that good germination results could be obtained by soaking seeds for $48 \mathrm{~h}$ initially in hot water [ 60 to $70^{\circ} \mathrm{C}$ ( 140 to $158^{\circ} \mathrm{F}$ ) and than allowing to cool to room temperature. Similar results were obtained in the present experiment with $\mathrm{H}$. rhamnoides subsp. turkestanica, and mongolica and $H$. neurocarpa, when the seeds were planted at the surface (Table 1).

For surface seeding, seeds soaked for $48 \mathrm{~h}$ in water or potassium nitrate solution at room temperature had greater emergence percentage than nontreated control in $\mathrm{H}$. rhamnoides 'Indian-Summer'. Preseeding treatments had no effect on emergence for $H$. rhamnoides subsp. rhamnoi desand 
Table 2. E ffects of seeding depths and seed treatments on the number of days to start seed emergence in sea buckthorn.

\begin{tabular}{|c|c|c|c|c|c|c|c|c|c|}
\hline \multirow{2}{*}{$\begin{array}{l}\text { Seeding } \\
\text { depth } \\
\text { [cm (inches)] }\end{array}$} & \multicolumn{9}{|c|}{ H ippophae rhamnoides and other sp. } \\
\hline & $\begin{array}{c}\text { Seed } \\
\text { treatment }\end{array}$ & $\begin{array}{l}\text { Indian } \\
\text { Summer }\end{array}$ & $\begin{array}{c}\text { subsp. } \\
\text { rhamnoides }\end{array}$ & $\begin{array}{c}\text { subsp. } \\
\text { turkestonica }\end{array}$ & $\begin{array}{l}\text { subsp. } \\
\text { sinensis }\end{array}$ & $\begin{array}{c}\text { subsp. } \\
\text { mongolica }\end{array}$ & $\begin{array}{c}\text { H. } \\
\text { salicifolia }\end{array}$ & $\begin{array}{c}\text { H. } \\
\text { tibertana }\end{array}$ & $\begin{array}{c}\text { H. } \\
\text { neurocarpa }\end{array}$ \\
\hline \multirow[t]{5}{*}{0} & Control & $3.0 a^{y}$ & $5.0 \mathrm{a}$ & $9.5 \mathrm{a}$ & $5.0 \mathrm{a}$ & $10.3 a$ & $16.2 \mathrm{a}$ & $7.0 \mathrm{a}$ & $6.0 \mathrm{a}$ \\
\hline & Water, RT & $3.0 \mathrm{a}$ & $3.0 \mathrm{~b}$ & $4.5 \mathrm{C}$ & $3.0 \mathrm{~b}$ & $5.0 \mathrm{~b}$ & $10.0 \mathrm{~b}$ & $3.0 \mathrm{~b}$ & $2.7 \mathrm{c}$ \\
\hline & Water, hot & $3.0 \mathrm{a}$ & $3.0 \mathrm{~b}$ & $3.7 \mathrm{c}$ & $3.0 \mathrm{~b}$ & $5.5 \mathrm{~b}$ & $11.7 \mathrm{~b}$ & $3.0 \mathrm{~b}$ & $2.0 \mathrm{c}$ \\
\hline & $\mathrm{GA}_{3}$ & $3.0 \mathrm{a}$ & $5.2 \mathrm{a}$ & $8.0 \mathrm{a}$ & $3.0 \mathrm{~b}$ & $N A^{x}$ & $11.0 \mathrm{~b}$ & $3.0 \mathrm{~b}$ & $4.0 \mathrm{bc}$ \\
\hline & $\mathrm{KNO}_{3}$ & $3.5 a$ & $3.0 \mathrm{~b}$ & $6.3 \mathrm{~b}$ & $3.0 \mathrm{~b}$ & NA & $10.8 \mathrm{~b}$ & $3.0 \mathrm{~b}$ & $2.7 \mathrm{c}$ \\
\hline \multirow[t]{5}{*}{$1(0.394)$} & Control & $12.4 \mathrm{~b}$ & $10.0 \mathrm{a}$ & $21.0 \mathrm{a}$ & $9.0 \mathrm{ab}$ & NA & $19.5 \mathrm{ab}$ & $14.4 \mathrm{a}$ & NA \\
\hline & Water, RT & $12.3 \mathrm{~b}$ & $10.0 \mathrm{a}$ & $15.5 \mathrm{~b}$ & $11.7 \mathrm{a}$ & $13.0 \mathrm{~b}$ & $21.5 \mathrm{a}$ & $12.7 \mathrm{a}$ & NA \\
\hline & Water, hot & $9.8 \mathrm{c}$ & --- & $5.8 \mathrm{~d}$ & $7.5 \mathrm{~b}$ & $16.0 \mathrm{a}$ & $17.8 \mathrm{~b}$ & $12.0 \mathrm{a}$ & NA \\
\hline & $\mathrm{GA}_{3}$ & $11.0 \mathrm{bc}$ & $11.5 \mathrm{a}$ & $11.3 \mathrm{c}$ & $10.0 \mathrm{a}$ & NA & $20.2 \mathrm{a}$ & $7.0 \mathrm{~b}$ & NA \\
\hline & $\mathrm{KNO}_{3}$ & $14.0 \mathrm{a}$ & $6.0 \mathrm{~b}$ & $18.3 \mathrm{ab}$ & $9.0 \mathrm{ab}$ & NA & $18.4 \mathrm{~b}$ & $3.0 \mathrm{c}$ & NA \\
\hline \multirow[t]{5}{*}{$2(0.788)$} & Control & $15.8 \mathrm{a}$ & $14.7 \mathrm{a}$ & $14.0 \mathrm{~b}$ & $12.8 \mathrm{a}$ & NA & $22.0 \mathrm{a}$ & $17.0 \mathrm{a}$ & NA \\
\hline & Water, RT & $14.0 \mathrm{~b}$ & $10.0 \mathrm{~b}$ & 13.7 b & $13.3 \mathrm{a}$ & NA & $19.6 \mathrm{a}$ & $7.0 \mathrm{C}$ & NA \\
\hline & Water, hot & $13.0 \mathrm{bc}$ & $10.0 \mathrm{~b}$ & $15.5 \mathrm{ab}$ & $9.0 \mathrm{~b}$ & NA & $20.3 a$ & $14.0 \mathrm{~b}$ & NA \\
\hline & $\mathrm{GA}_{3}$ & $14.3 \mathrm{~b}$ & $10.0 \mathrm{~b}$ & $16.0 \mathrm{a}$ & $10.3 \mathrm{~b}$ & NA & $21.7 \mathrm{a}$ & $5.7 \mathrm{c}$ & NA \\
\hline & $\mathrm{KNO}_{3}^{3}$ & $11.0 \mathrm{C}$ & $10.0 \mathrm{~b}$ & $15.5 \mathrm{ab}$ & $13.0 \mathrm{a}$ & NA & 19.6 a & -- & NA \\
\hline
\end{tabular}

zSeed treatment: water, RT (room temperature) = soaked in water under room temperature $\left[20^{\circ} \mathrm{C}\left(68^{\circ} \mathrm{F}\right)\right]$; water, hot $=$ soaked in preheated $\left[70^{\circ} \mathrm{C}\left(158{ }^{\circ} \mathrm{F}\right)\right.$ water and allowed to cool to room temperature; $\mathrm{GA}_{3}=500 \mathrm{mg} \cdot \mathrm{L}^{-1}$ solution; $\mathrm{KNO}_{3}=$ soaked in potassium nitrate at $0.01 \mathrm{M}$.

'Values within each column and within a seeding depth with a common letter are not significantly different $(p=0.05)$ according to D uncan's new multiple range test. ×N A = not applied.

snensis. Higher emergence percentageswereobserved for preseeding treatments with $\mathrm{GA}_{3}$ or potassium nitrate for $\mathrm{H}$. salicifolia and the latter for $\mathrm{H}$. tibetana and $H$. rhamnoides subsp. turkestanica (Table 1).

$\mathrm{Lu}$ (1992) reported that seeds of $H$. rhamnoidessubsp. sinensisrequired 12 to $18 d$ to sprout when seeds were sown at the depth of 1 to $2 \mathrm{~cm}$ in the field with air temperature of 15 to 20 ${ }^{\circ} \mathrm{C}\left(59\right.$ to $\left.68^{\circ} \mathrm{F}\right)$. In the present study, seeds of the same species planted 1 or 2 $\mathrm{cm}$ deep, with $25 / 20{ }^{\circ} \mathrm{C}$ day/ night, required average of 9.0 and $12.8 \mathrm{~d}$, respectively to emerge(Table 2$)$. When the seeds were planted at the surface, preseeding water-soaking treatmentssignificantly reduced the number of days to emergence for all species except $\mathrm{H}$. rhamnoi des'I ndian-Summer' (T able2). Seeds soaked in water and $\mathrm{GA}_{3}$ solution shortened the number of days required to emerge for $\mathrm{H}$. rhamnoides subsp. turkestonica. Seeds of $H$. rhamnoides subsp. rhamnoidessoaked in potassium nitrate solution needed fewer number of days to emerge planted at the depth of $1 \mathrm{~cm}$. All preseeding treatments hastened or speeded emergence of $\mathrm{H}$. rhamnoides 'Indian-Summer' and $H$. rhamnoides subsp. rhamnoides at the planting depth of $2 \mathrm{~cm}$, however, treatments had no effect on $\mathrm{H}$. rhamnoides subsp. turkestonica and $\mathrm{H}$. salicifolia. (Table 2).

Table 3. Effects of seeding depths and seed treatments on the number of days required to complete seed emergence on in sea buckthorn.

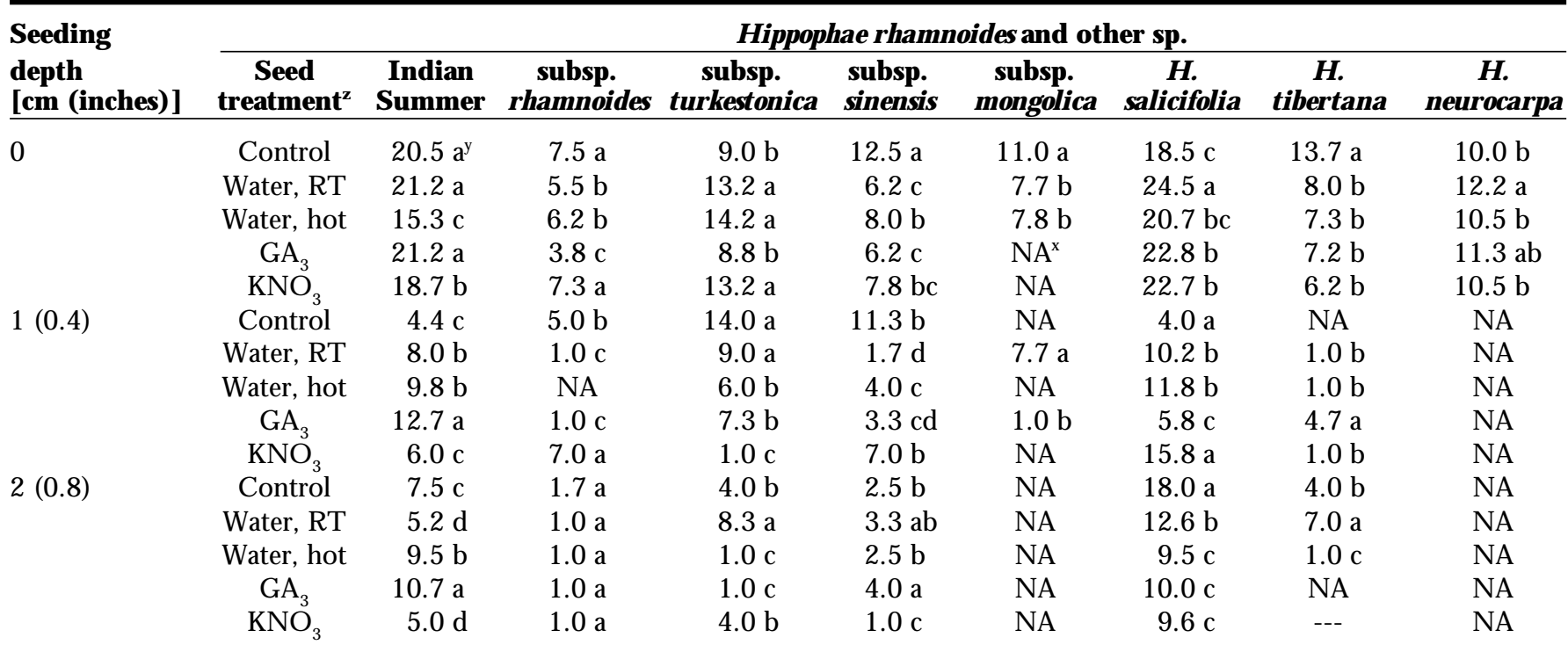

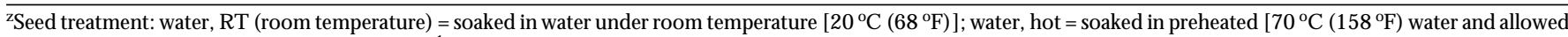
to cool to room temperature; $\mathrm{GA}_{3}=500 \mathrm{mg} \cdot \mathrm{L}^{-1}$ solution; $\mathrm{KNO}_{3}=$ soaked in potassium nitrate at $0.01 \mathrm{M}$.

W alues within each column and within a seeding depth with a common letter are not significantly different $(p=0.05)$ according to D uncan's new multiple range test.

×N A = not applied. 


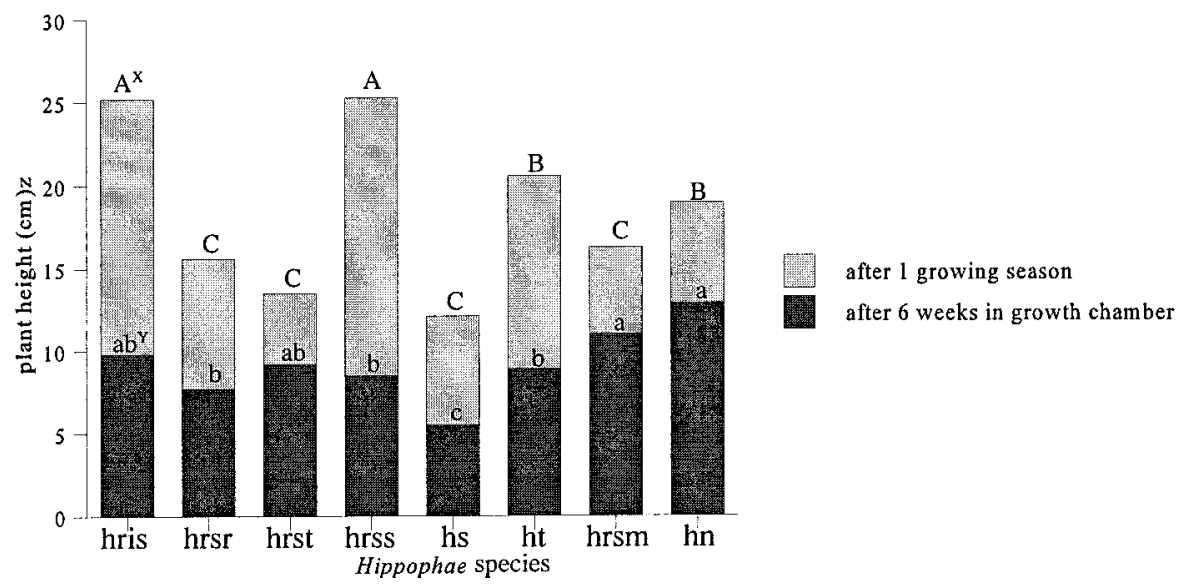

Fig. 1. Average plant height of $\mathrm{H}$ ippophae species. $\mathrm{H}$ ippophae species: hris $=H$. rhamnoides L. 'I ndianSummer'; hrsr = H . rhamnoides subsp. rhamnoides, hrst $=H$. rhamnoides subsp. turkestanica; hrss = $H$. rhamnoides subsp. sinensis; hs $=\mathbf{H}$. salicifolia; ht $=\mathbf{H}$. ti betana; $\mathbf{h r s m}=\mathbf{H}$. rhamnoides subsp. mongolica; and hn $=\mathrm{H}$. neurocarpa. ${ }^{*, * *}$ Values in each bar with a common letter, in upper and lower case, are not significantly different $(p=0.05)$ according to Duncan's new multiple range test; $2.54 \mathrm{~cm}=1.0$ inch .

Control seedstook longer to complete emergence when they were planted at the surface than at 1 or $2 \mathrm{~cm}$ for all species except $\mathrm{H}$. rhamnoides subsp. turkestanica, mongolica, and H . salicifolia (T able3). H owever, seed soaked in water or potassium nitrate solution shortened thenumber of days required to complete germination for $H$. rhamnoides 'I ndian-Summer', $H$. rhamnoides subsp. sinensis, and $H$. tibetana compared to the control (Table 3). The $\mathrm{GA}_{3}$ solution reduced the germination period of $\mathrm{H}$. rhamnoides subsp. rhamnoides, turkestanica and sinensis at a $1-\mathrm{cm}$ depth and $H$. rhamnoides subsp. rhamnoides, turkestanica, and $\mathrm{H}$. salicifolia at a 2-cm depth. In general, preseeding treatmentsresulted in fewer days required to start and complete emergence when compared with the nontreated control (T ables2 and 3). A shorter period to complete seed emergence produced more uniform seed-
Fefelov, V.A. and I.P. Eliseev. 1986. Biology of germination and emergence of sea buckthorn seeds of different ecological and geographical origin. BiologiyaK himiya Introducktsiya i Selektsiya Oblepikhi 1986:110-115.

Li, D., Y. Liang, and X. Cong. 1995. $B$ enefits and prospects of aerial sowing of sea buckthorn on the Loess Plateau of China, p. 139-150. In: S. Lu (ed.). Proc. Intl. Workshop on Seabuckthorn, Beijing.

Li, T.S.C. and W.R. Schroeder. 1996. Sea buckthorn (H ippophae rhamnoides L.): A multipurpose plant. HortT echnology 6:370-380

lings which is an important factor for the success of orchard-type cultivation.

Seedlings from eight species or subspecies tested had significantly different heights after one growing season. $H$. rhamnoides subsp. mongolica and $H$. neur ocarpa started their growth vigorously in the growth chamber and slowed down as soon as seedlingswere transplanted to the field. O $\mathrm{n}$ the other hand, $H$. rhamnoides subsp. sinensis and $H$. rhamnoides 'I ndian-Summer' thrived in the field and had significantly higher growth increments (Fig. $1)$. These phenomena reflect their growth habits as either tree- or bushtype due to genetic variation within the genus $H$ ippophae. $H$. salicifolia and $H$. rhamnoides subsp. snensis are tree forms, which grow up to 10 and $16 \mathrm{~m}$ (32.8 and $52.5 \mathrm{ft}$ ), respectively. $\mathrm{O} n$ the other hand, $\mathrm{H}$. tibetana is a densely branched dwarf shrub $<0.5 \mathrm{~m}$ (1.6 ft) high (Rousi, 1971).

\section{Literature cited}

Eliseev, I.P. and I.A. M ishulina. 1972a. $\mathrm{N}$ ew data on the biology of germination of $\mathrm{H}$ ippophae rhamnoides seeds. Trudy Gorkovskogo Sel'skokhozyaistvennogo Inst. 38:107-109.

Eliseev, I.P. and I.A. M ishulina. 1972b. The effect of the minor elements on the increase in sea buckthorn (Hippophae rhamnoides) seed germination. Trudy Gor'kovskogo Sel'skokhozyaist-vennogo Inst. 38:110-111.
Li, T.S.C. and L.C.H . Wang. 1998. Physiological components and health effects of ginseng, echinacea and sea buckthorn, $p$. 185-203. In: G.M azza (ed.). Functional foods: processing aspects of food for health benefits. Technomic Publ. L ancaster, Pa.

Lu, R. 1992. Sea buckthorn: A multipurpose plant species for fragile mountains. Intl. Centre for Integrated M ountain D evelopment (ICIMOD) O ccasional paper 20, Katmandu, N epal.

M cKeague, J.A. 1978. The Canadian system of soil classification. Canada Dept. Agr. Publ. 1646.

Rousi, A. 1971. The genusH ippophaeL . A taxonomic study. Ann. Bot. Fennici 8:177227.

Salo, K. 1991. The initial development of the Chinese sea buckthorn, $\mathrm{H}$ ippophae rhamnoides subsp. snensis in the greenhouse. Luonnon Tutkija 95:150-155.

SASI nstitute, Inc. 1990. SAS/ ST AT users guide. version 6, 4th ed. SAS, Cary, N.C.

Siabaugh, P.E. 1974. H ippophae rhamnoides-Common sea buckthorn, $p$. 446-447. I n: C. S. Schopmeyer (ed.). Seeds of woody plantsin theU nited States. U SD A Agr. H dbk. 450.

Vernik, R.S. and U .N. Zhapakova. 1986. Biology of seed germination in $\mathrm{H}$ ippophae rhamnoides. U zbekskii Biologicheskii Zhurnal 5:38-40.

Zu, Z., F. Ao, Y. Xin, and L. Yang. 1993. Relationship between seedssprouting, and temperature of $\mathrm{H}$ ippophae in China, $\mathrm{p}$. 333-341. In: P.L. Goncharov (ed.). Proc. 2nd Intl. Symp. on Sea Buckthorn (H ippophae rhamnoides L.), M oscow. 